\title{
Carbon Fluxes in a Managed Pine Forest Under Ambient and Elevated $\mathrm{CO} 2$
}

\author{
Ram Oren, Gabriel Katul, Karina Schafer, Cheng-1 Hsieh \\ School of the Environment, Duke University, Durham, NCF \\ David Ellsworth, George Hendrey \\ Brookhaven National Laboratory, Upton, NY
}

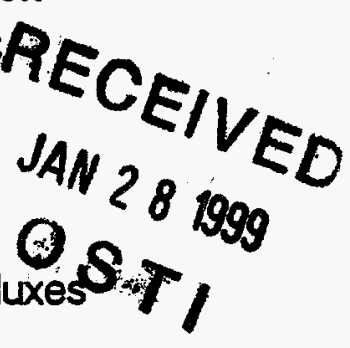

Objectives: The primary objective of this stuoy is to estimate $\mathrm{CO}_{2}$
$\left(\mathrm{~F} \mathrm{Co}_{2}\right)$ under ambient and elevated atmospheric $\mathrm{CO}_{2}$ and varying environmental conditions. Additional objectives are to: (2) quantify canopy conductance and evaluate the hypothesis that canopy conductance will not be altered by elevated atmospheric $\mathrm{CO}_{2}$ because reduction in leaf conductance is compensated by increased leaf area index, and (3) quantify the effect of elevated $\mathrm{CO}_{2}$ on aboveground production and apparent allocation of carbon belowground. In order to achieve the primary objective, we propose a modification to a methodology proposed earlier which emphasized leaf level measurements. These modifications stem from analysis of measurements performed in 1995-1996 that demonstrate (i) high variability in $\mathrm{CO}_{2}$ assimilation $(A)$ - intemai concentration $\left(C_{i}\right)$ relations $\left(A-C_{1}\right.$ curves) in each level in the canopy for given photosynthetically active radiation (PAR) and soil moisture content $(\theta)$ conditions, (ii) the relative independence of the ratio of $\mathrm{C}_{i}$ to atmospheric $\mathrm{CO}_{2}$ concentration $\left(\mathrm{C}_{\mathrm{C}} / \mathrm{C}_{2}\right)$ from $\mathrm{Ca}_{\mathrm{a}}$ (different levels within canopy for a wide range of moisture content conditions), (iii) similarity in $\mathrm{CO}_{2}$ and water vapor flux co-spectra which permits estimation of $\mathrm{CO}_{2}$ conductances from water vapor conductances for canopy trees, and (iv) the good correlation ( $r=0.94$ ) between scaled 15-tree stem flux measurements and eddy correlation water vapor flux on a daily time step.

Products: The expected products from this project include: (1) Evaluation of a new method to predict the assimilation rate of $\mathrm{CO}_{2}$ from a simplified physiological relationship between internal and extemal $\mathrm{CO}_{2}$ concentration, climatic variables, sap flux measurements, and similarity in canopy conductances to $\mathrm{CO}_{2}$ and water vapor, (2) Based on the proposed method, a quantified effect of elevated $\mathrm{CO}_{2}$ on canopy conductance and net $\mathrm{CO}_{2}$ flux, including interactions with hydrologic and climatic variables, (3) Evaluation of the differential response of co-occurring species to elevated $\mathrm{CO}_{2}$ in-terms of total conductance, and (4) Quantified effect of elevated atmospheric $\mathrm{CO}_{2}$ on aboveground production and on soil respiration, the latter measured during FACE downtime.

Approach: Eddy-covariance based $\mathrm{CO}_{2}$ and $\mathrm{H}_{2} \mathrm{O}$ fluxes were estimated at the Duke Forest Ameriflux site (15-year-old loblolly Pine forest) from August 1997-June 1998 for an ambient ring (Ring 1) within the FACE project

*This research was performed under the auspices of the U.S. Department of Energy under contract no. DE-AC02-98CH10886. 
together with meteorological, soil moisture, and xylem sapflux measurements. The data was processed till April of 1998 and preliminary results are shown below.

Results to Date: The project results to date are:

1. Canopy conductance to water vapor for ambient and elevated $\mathrm{C}_{\mathrm{a}}$ were calculated. The values indicate that, during the first year of exposure to elevated $\mathrm{CO}_{2}$, conductance decreased such that the stand within the FACE plot transpired approximately $25 \%$ less water when compared to a reference stand. However, during the second year of exposure, lowered canopy conductance was apparent only at low vapor pressure deficit (VPD) conditions. Combined with a greater increase in LAl in the FACE plot, transpiration in the second year was only $10 \%$ less than in the reference plot. By the third year, differences between the FACE and reference plots were undetectable.

2. Preliminary comparison of biomass production (based on measured diameter at breast height and biomass equations) indicates large response to $\mathrm{CO}_{2}$ enrichment. Production at the FACE prototype during the second year of fumigation was about $50 \%$ higher than in the adjacent reference stand; during the first 13 years of the forest's life, growth was slightly greater in the reference stand. By the third year, stemwood production in the prototype plot was only ca. $20 \%$ greater than in the reference plot, and was less than that in the reference by the end of the fourth year. We are currently investigating the possibility that nutrient limitation is responsible for the recent decrease in growth in the prototype plot.

3. A new closure model for estimating multilevel $\mathrm{CO}_{2}$ sources, sinks, and fluxes was developed and field -tested. The model requires mean velocity, leaf area density, foliage drag, and $\mathrm{CO}_{2}$ concentration profiles inside and above the canopy. Good agreement between $\mathrm{CO}_{2}$ eddy covariance measured and predicted fluxes was obtained $\left(r^{2}=0.71\right)$ at $9 \mathrm{~m}$ above the ground surface (canopy height is $14 \mathrm{~m}$ ).

4. Leaf-level measurements $\left(A-C_{i}\right.$ curves) over a range of environmental conditions suggest that elevated atmospheric $\mathrm{CO}_{2}$ did not alter the functional relationship between $A$ and $C_{i}$. The measurements also demonstrated that high variability occurs amongst curves generated under similar environmental conditions; hence, integrating leaf-level $\mathrm{A}-\mathrm{C}_{i}$ curves parameter to stand level introduces large uncertainties to $\mathrm{CO}_{2}$ budget calculations. However, the same measurements demonstrate that the ratio $\mathrm{C}_{i} / \mathrm{C}_{\mathrm{a}}$ is insensitive to variability in $\mathrm{C}_{\mathrm{a}}$ for both ambient and FACE operating conditions (ca. 300-600 ppm).

5. From the AmeriFlux eddy-covariance measurements, from August 1997 - 


\section{DISCLAMMER}

This report was prepared as an account of work sponsored by an agency of the United States Government. Neither the United States Government nor any agency thereof, nor any of their employees, makes any warranty, express or implied, or ascumes any legal liability or responsibility for the accuracy, coropieteaess, or usefulness of any information, apparatus, product, or process disclosed, or represents that its use would not infringe privately owned rights. Reference berin to any specific commercial product, process, or service by trade name, trademart, manufacturer, or otherwise does not necessarily constiute or imply its endorsement, recommendation, or favoring by the United States Government or any ageacy thereor. The views and opinions of authors expressed bercin do not necessarily state or reflect those of the. United States Government or any agency thereof. 


\section{DISCLAIMER}

Portions of this document may be illegible in electronic image products. Images are produced from the best available original document. 
April 1998, latent heat flux, day time net ecosystem $\mathrm{CO}_{2}$ uptake, nighttime respiration, and net monthly ecosystem $\mathrm{CO}_{2}$ uptake were computed. In December and January, $\mathrm{CO}_{2}$ fluxes frequent frost and stable atmospheric conditions resulted in too few runs to obtain a reliable average for these two months for $\mathrm{CO}_{2}$. Figure 1 shows the preliminary monthly water and $\mathrm{CO}_{2}$ budgets.

Students: Nathan Phillips (Ph.D - Spring 1997) has been hired for the summer of 1997 to complete the analyses of sapflux data, and link it to soil and atmospheric variables. Cheng-I Hsieh (Ph.D. - Spring 1998) performed eddy covariance measurements and data analyses. Diane E. Pataki (part time, Ph.D. - Spring 1998) continued sapflux measurements and performed canopy conductance calculations.

\section{Publications (1997-1998):}

Hsieh, C.I., G.G. Katul, J. Scheildge, J.T. Sigmon, and K.K. Knoerr (1997). The lagrangian stochastic model for fetch and latent heat flux estimation above uniform and non-uniform terrain. Water Resources Research, 33, 427-438.

Katul, G.G., and B. Vidakovic (1998) Identification of Low-Dimensional Energy Containing/Flux Transporting eddy Motion in the Atmospheric Surface Layer Using Wavelet Thresholding Methods. Journal of the Atmospheric Sciences, 55, 377-389.

Katul, G.G., and C.R. Chu (1998) A Theoretical and Experimental Investigation of the Energy-Containing Scales in the Dynamic Sublayer of Boundary-Layer Flows. Boundary Layer Meteorology, 86, 279-312.

Katul, G.G., C.D. Geron, C.I. Hsieh, and B. Vidakovic, and A. Guenther (1998) Active turbulence and scalar transport near the forest-atmosphere interface. Joumal of Applied Meteorology, In press.

Katul, G.G., C.I. Hsieh, G. Kuhn, D. Ellsworth, D. Nie (1997) The turbulent eddy motion at the forest-atmosphere interface. Journal of Geophysical Research, 102, 13409-13421.

Katul, G.G., G. Kuhn, J. Scheildge, C.I. Hsieh (1997) The Ejection-Sweep Character of Scalar Fluxes in the Unstable Surface Layer. Boundary Layer Meteorology, 83, 1-26.

Katul, G.G., J. Schieldge, C.I. Hsieh, and B. Vidakovic (1998) Skin temperature perturbations induced by surface layer turbulence above a grass surface. Water Resources Research, 34, 1265-1274.

Oren, R., B.E. Ewers, P. Todd, N. Phillips, and G. Katul (1998) Water balance delineates the soil layer in which moisture affects canopy conductance. Ecological Applications, In press.

Oren, R., N. Phillips, G. Katul, B.E. Ewers, D.E. Pataki (1998) Scaling xylem sap flux and soil water balance and calculating variance: a method for partitioning water flux in forests. Annales des Sciences Forestieres, 55, 191216. 
Pataki, D.E., R. Oren, and N. Phillips (1998) Responses of sap flux and stomatal conductance of Pinus taeda $L$. trees to stepwise reductions in leaf area. Joumal of Experimental Botany, 49, 871-878.

Phillips, N. and R. Oren (1998) A comparison of daily representations of canopy conductance based on two conditional time-averaging methods and the dependence of daily conductance on environmental factors. Annales des Sciences Forestieres, 55, 217-235.

Phillips, N., A. Nagchaudhuri, R. Oren, and G. Katul (1997) Time constant for water transport in loblolly pine trees estimated from time series of evaporative demand and stem sapflow. Trees: Structure and Function, 11, 412-419.

Figure 1: Carbon Dioxide Fluxes and Evapotranspiration at the Duke Forest Ameriflux Pinus taeda site.
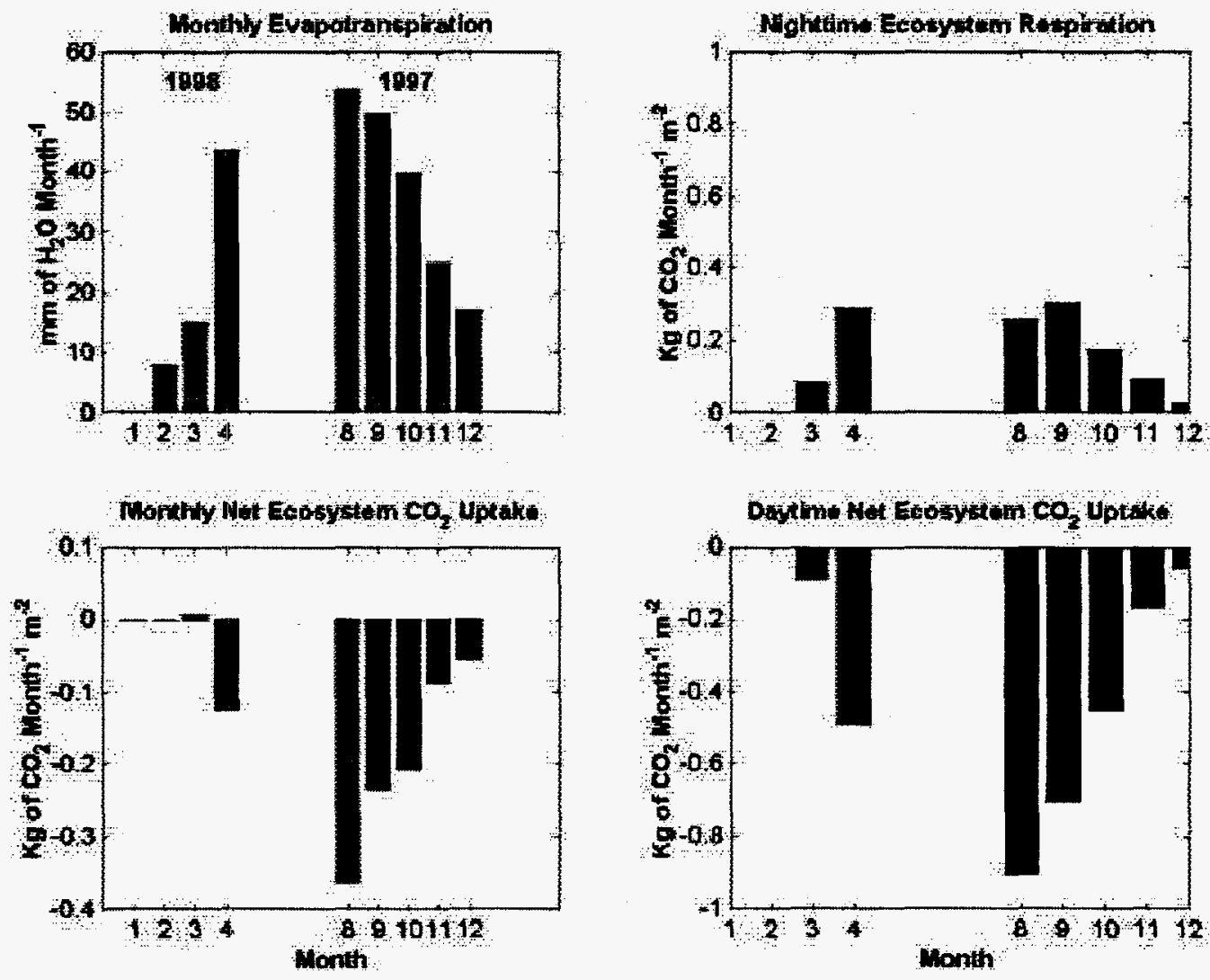